\title{
Calculation of Pollutant Load in Cipunagara River: Livestock Sector
}

\author{
Iwan Juwana*, Diki Prastyo Nugroho \\ Department of Environmental Engineering, Institut Teknologi Nasional (ITENAS), INDONESIA \\ JL. PHH Mustafa 23 Bandung 40123, West Java \\ *Corresponding authors: juwana@itenas.ac.id
}

SUBMITTED 18 December 2019 REVISED 03 February 2020 ACCEPTED 07 April 2020

\begin{abstract}
Cipunagara is the largest watershed in Subang Regency with River Cipunagara as the mainstream. Previous works showed increased activities around Cipunagara watershed, especially in segment 3, leading to a decline in the water quality. The importance of this river increases due to the development plan of Sadawarna and Cilame Reservoirs, which are used for irrigation and other activities. This study aims to identify pollution sources and to analyze the capacity of Cipunagara River in relation to potential pollution load from the watershed for the next 5 years. The study focuses on livestock, which is one of the main sectors contributing to pollution. The main steps include segment selection, calculation of existing pollutant load and prediction within the next 5 years from livestock waste. The segment selection was based on the number of activities from several sectors, the spatial plan of the region, as well as the quality and quantity Cipunagara River. The calculation of existing pollutant load was based on actual pollutant and flow of the river, while the prediction of pollutant load relied on emission factor of each pollutant parameter. The results showed that pollution index in Cipunagara River was severe. The existing and the projected potential pollutant loads in segment 3 include 1,668.76 kg/day and 2,081.25 kg/day for BOD; $4,053.74 \mathrm{~kg} /$ day and 5,063.29 kg/day for COD; $8.72 \mathrm{~kg} /$ day and $13.34 \mathrm{~kg} /$ day for N-Total; and $1.75 \mathrm{~kg} /$ day and $2.16 \mathrm{~kg} /$ day for P-Total, respectively. These results can be used by the local governments to manage water quality of the river.
\end{abstract}

KEYWORDS Cipunagara Watershed; Pollution Index; Pollutant Load; Livestock; Emission Factor.

(c) The Author(s) 2020. This article is distributed under a Creative Commons Attribution-ShareAlike 4.0 International license.

\section{INTRODUCTION}

Rivers in West Java are used for different purposes, such as agricultural irrigation facilities, drinking water sources, and industrial functions (Asdak, 2002; Juwana, et al., 2014; Sari, et al., 2018). One of the main rivers is Cipunagara, which is the largest in Subang Regency and currently belongs to Class II of water quality. It originates from Cipunagara spring, the southern boundary being Subang adjacent to Bandung Regency and flows into the Java Sea. There are different Land uses around the Cipunagara watershed, including forestry, plantations, rice fields, settlements, livestock, industry, mangrove forests, and fishponds.

The population growth in Cipunagara Watershed and other human activities have influenced the utilization of the natural resources. The existing resources cannot adequately provide for the need of the needs of the growing population, which negatively impact the environment. For instance, the excessive use of natural resources may disrupt the water balance (Hikmat and Juwana, 2019; Yogaswara, et al., 2019; Hidrijanti, et al., 2019). The livestock sector significantly contributes to the disruption of water balance, especially in Cipunagara River.

Considering the conditions and functions of the Cipunagara River, there is an increasing need for management of water resources from upstream to downstream (Yang, et al., 2018). However, robust management strategies cannot be identified without clear information on the pollution load to the river, which is not yet available. Information on the pollution load capacity in Cipunagara, 
particularly from the livestock sector, is needed. It is necessary to identify and to calculate the pollution load capacity of Cipunagara Watershed to help the local government formulate water pollution control strategy (Effendi, 2003). The information obtained is also vital for using the river as raw water source, which may shift its status from Class II to Class I of the Standard Water Quality for River.

The purpose of this study is to analyze pollution load capacity in the Cipunagara River to identify pollutants and calculate their load, as well as their potential pollution level. It aims to provide recommendations on the pollution control strategy in the Cipunagara Watershed. The overall study identifies pollution load from four different sectors, including domestic, industry, agriculture and livestock. This paper discusses the calculation pollution from the livestock sector. The discussion in this manuscript is structured into two main parts, including segment selection and its analysis. In the segment selection, calculation for the pollution load is based on Class II as its current river status, while the analysis is based on Class I as in the future, segment 3 will be used as the source of raw water for drinking.

\section{METHODS}

\subsection{Data Collection}

Data collection is divided into two, primary and secondary. The primary data includes interviews with West Java Provincial Officer of Environment Agency which manages Cipunagara Watershed, and the survey of its existing condition, including the physical conditions of Cipunagara River and interviews with local authorities. Secondary data includes water quality and quantity data, Cipunagara Watershed map, point and non-point pollution sources, distribution of domestic, agriculture, livestock and industry activity, population, agricultural land area, number of livestock for the last 10 years and Document of Spatial Plan (RTRW).

\subsection{Assessment of Water Quality Status}

The assessment of water quality status aims to determine the quality of water and the state of the pollution. Water quality status was determined using pollution index method listed in Indonesia Ministry of Environment Decree No. 115 Year 2003. This approach directly links the level of contamination with certain use and the value of certain parameters. The result of the assessment of water quality status is used as the basis for calculation in the next stage (Hallock, 1988). The reference used in the assessment of the status of water quality is presented in Table 1 .

Table 1. Assessment of water quality status

\begin{tabular}{ll}
\hline Index & Classification \\
\hline $0 \leqslant \mathrm{PIj} \leqslant 1$ & Meet the Quality Standard \\
$1<\mathrm{PIj} \leqslant 5$ & Mildly Polluted \\
$5<\mathrm{PIj} \leqslant 10$ & Medium Polluted \\
$\mathrm{PIj}>10$ & Highly Polluted \\
\hline
\end{tabular}

\subsection{Segment Selection}

The selection of the river segment was conducted by scoring on the number of activities from several sectors, the spatial plan of the region, the quality and quantity of water, and the availability of other supporting data on the calculation of pollution load capacity.

\subsection{Existing Pollutant Load Calculation}

Maximum pollutant load should be calculated first to obtain the actual pollutant load. An example is given as follows.

\subsubsection{Maximum Pollutant Load (BPM)}

The Calculation maximum pollutant load is performed as a basis for comparison of the existing pollutant load and the potential for pollutant load. $B P M$ is obtained by multiplying flow with concentration and its conversion factor, as shown in Equation (1).

$B P M=Q \times C B M$

Where $B P M$ is the maximum pollutant load ( $\mathrm{kg} / \mathrm{day}), Q$ is measurable flow $\left(\mathrm{m}^{3} / \mathrm{s}\right)$, and $C B M$ is 
maximum concentration (Standards from the Government Regulation of Indonesia No. 82/2001 on Water Quality Management and Water Pollution Control, Class I).

\subsubsection{Actual Pollutant Load Calculation (BPA)}

The calculation of the actual pollutant load is, in principle, similar to the calculation of the BPM. The difference only lies in the concentration used, as shown in Equation (2).

$B P A=Q \times C$

Where $B P A$ is actual pollutant load ( $\mathrm{kg} / \mathrm{day}), Q$ is measurable flow $\left(\mathrm{m}^{3} / \mathrm{s}\right)$, and $C M$ is measurable concentration (mg/L).

\subsection{Predicted Pollutant Load Calculation}

The calculation of the projection of the load is derived from non-point source pollutants from livestock sector activities ( $\mathrm{Wu}, 2006)$. The formula used in the calculation is shown in Equation (3).

Pollution Load $=\sum$ livestock $\times$ Emission Factor $\times 20 \%(3)$

Where Pollutant Load is the Projected Pollutant load, Elivestock is the number of estimated livestock, and $20 \%$ is the value of the runoff ratio indicating that the load entering the river is derived from a non-point source (Iskandar, 2007).The key parameters include BOD, COD and Nutrients (compounds $\mathrm{N}$ and $\mathrm{P}$ ), which are commonly found in polluted river with the probability of occurrence $\geqslant 80 \%$ (Iskandar, 2007). These parameters are also selected based on emission factors for livestock. The emission factor is derived from pre-existing research developed by Balai Lingkungan Keairan, Puslitbang SDA, Ministry of Public Works of Indonesia. Emission factors used is based on livestock releases reference from pre-existing research (Yusuf, 2014). These factors are used due to the similarity of study location used in previous work with the one in Cipunagara.

The projected pollutant load was analyzed using arithmetic, geometric and least square method (Isserman, 1977). The approach is based on existing data from livestock that considers the information contained in the RTRW document, which focuses on the development of the livestock sector in the Cipunagara Watershed.

\subsection{The Calculation of Pollution Index}

Pollution Index is one of the indicators for segment selection. The equations for the calculation are shown in Equation (4) to (7), as follow.

1. $\mathrm{Ci} / \mathrm{Lij}$ of parameters that have no range (BOD)

$$
C i{ }_{\text {Lij }}=\frac{\text { Concentration of sampled } B O D}{\text { Maximum concentration allowed }}
$$

2. $\mathrm{Ci} / \mathrm{Lij}$ of paramaters with range $(\mathrm{pH})$

$$
C i{ }_{L i j}=\frac{C i-(L i j) \text { Average }}{(L i j) \text { Max }-(L i j) \text { Average }}
$$

3. $C i / L i j$ of paramaters when the values are low, the water quality decreases (DO)

$$
C i{ }_{L i j}=\frac{\text { Cim-(Ci)Measurement }}{\text { Cim-Lij }}
$$

4. Pollution Index

$$
P I j=\sqrt{(}(C i / L i j) 2 \mathrm{Max}+(C i / L i j) 2 \text { Average }) / 2
$$

Table 2. Emission Factor for Different Livestocks

\begin{tabular}{lllll}
\hline \multirow{2}{*}{ Type of Livestock } & \multicolumn{4}{c}{ Emission factor (gr/animal/day) } \\
\cline { 2 - 5 } & BOD & COD & N-Tot & P-Tot \\
\hline Cow & 292.00 & 717.00 & 0.933 & 0.153 \\
Buffalo & 207.00 & 530.00 & 2.600 & 0.390 \\
Horse & 226.00 & 558.00 & 38.080 & 0.300 \\
Sheep & 34.10 & 92.90 & 1.620 & 0.003 \\
Goat & 55.70 & 136.00 & 0.270 & 0.063 \\
Chicken & 2.36 & 5.59 & 0.002 & 0.003 \\
Duck & 0.88 & 2.22 & 0.001 & 0.005 \\
\hline
\end{tabular}




\section{RESULTS AND DISCUSSIONS}

\subsection{Segment Selection}

The Cipunagara watershed is divided into four segments. However, only one segment is selected because of time and resource limitation. In determining the segment, criteria for the selection includes existing distribution, water quality status and RTRW document. Segment selection is based on scoring and analysis of comparative results from the aspects reviewed. Scoring is based on quantitative data of each segment, including size, population, industry distribution, agriculture, livestock, water quality status and extent of RTRW, such as protected area, cultivation and quantity of development around Cipunagara Watershed. Figure 1 shows the segment map of Cipunagara Watershed.

\subsubsection{Assessment of Water Quality Status}

Assessment of water quality status conducted on the Cipunagara River in 2016 is designated as Class II water quality with the results include

- Water Quality Measures June 2016: Highly Polluted

- Water Quality Measures August 2016: Highly Polluted

- Water Quality Measures October 2016: Highly Polluted

Calculation examples are as follows

1. Parameter with no range (BOD):

Value of BOD: $9 \mathrm{mg} / \mathrm{L}$

Quality Standard of BOD: $3 \mathrm{mg} / \mathrm{L}$

$$
\begin{aligned}
\mathrm{Ci} / \mathrm{Lij} & =4.5 \mathrm{mg} / \mathrm{L} \\
\mathrm{Ci} / \text { LijNew } & =1+\mathrm{P} . \log (\mathrm{Ci} / \mathrm{Lij}) \text { Measurement } \\
& =1+5 \log (3 \mathrm{mg} / \mathrm{L}) \\
& =3.38
\end{aligned}
$$

Where $C i$ is the actual concentration, and $L i j$ the respective threshold value of Class II from the Standards based on the Government Regulation of Indonesia No. 82/2001

2. Parameter with range $(\mathrm{pH})$ :

Value of pH: 7.89

Quality Standard of pH: 6-9

$$
\begin{aligned}
\text { Ci } / \text { Lij } & =\frac{\text { Ci }-(\text { Lij }) \text { Average }}{(\text { Lij)Max }-(\text { Lij }) \text { Average }} \\
& =(7.89-7.50) /(9.00-7.50) \\
& =0.26
\end{aligned}
$$

3. Parameters when the values are low, the water quality decreases (DO):

Value of DO: $2.7 \mathrm{mg} / \mathrm{L}$

Quality Standard of DO: $4 \mathrm{mg} / \mathrm{L}$

$$
\begin{aligned}
\mathrm{Ci} / \mathrm{Lij} & =\frac{\text { Cim }-(\mathrm{Ci}) \text { Measurement }}{\text { Cim }- \text { Lij }} \\
& =(10.0-2.7) /(10.0-4.0) \\
& =1.21 \\
\mathrm{Ci} / \mathrm{LijNew} & =1+\mathrm{P} . \log (\mathrm{Ci} / \mathrm{Lij}) \text { Measurement } \\
& =1+5 \log (1.21 \mathrm{mg} / \mathrm{L}) \\
& =1.42
\end{aligned}
$$

4. Pollution Index

$$
\begin{aligned}
& P I j=\sqrt{(}(\mathrm{Ci} / \mathrm{Lij}) 2 \mathrm{Max}+(\mathrm{Ci} / \mathrm{Lij}) 2 \text { Average }) / 2 \\
& =\sqrt{((6.65) 2 \mathrm{Max}}+(0.97) 2 \text { Average }) / 2 \\
& =21.82 \text { (Highly Polluted) }
\end{aligned}
$$

\subsubsection{Comparison of the Segments}

The results of the segment comparison are presented in Table 3. The scoring used is based on several criteria considering the relation between the aspects reviewed and the polluted load results to be calculated (Trofisa, 2011). The criteria for scoring on segment selection are presented in Table 4 and the results are shown in Table 5. 

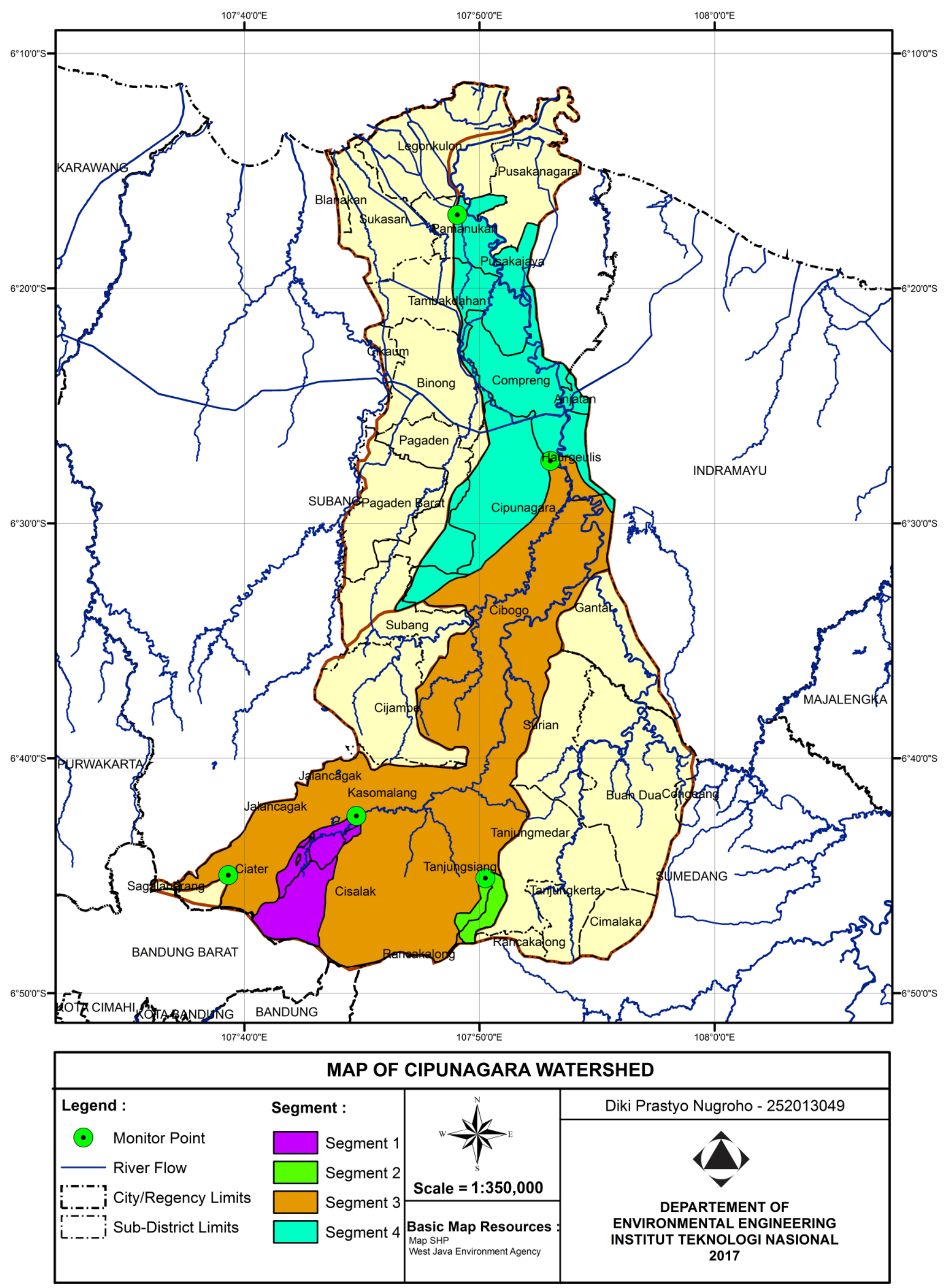

Figure 1. Map of Cipunagara Watershed. 
Table 3. Comparison of Cipunagara Watershed Segments

\begin{tabular}{lllll}
\hline & \multicolumn{4}{c}{ Segment of Cipunagara Watershed } \\
\hline Review & $\mathbf{1}$ & $\mathbf{2}$ & $\mathbf{3}$ & $\mathbf{4}$ \\
\hline Review of Existing Distribution: & & & & \\
Segment Area (Ha) & 3,835 & 1,125 & 42,468 & 19,407 \\
Total Population (Person) & 5,611 & 4,095 & 42,447 & 115,643 \\
Total Industry/SME & 8 & - & 14 & 12 \\
Area of Agricultural Land (Ha) & 1,825 & 244 & 23,489 & 25,828 \\
$\begin{array}{l}\text { Total of Livestock (number of } \\
\text { animals) }\end{array}$ & 162,581 & 56,225 & $1,570,245$ & 525,144 \\
\hline
\end{tabular}

\section{Review of Water Quality Status:}

\begin{tabular}{|c|c|c|c|c|}
\hline June 2016 & $\begin{array}{l}\text { Meet the } \\
\text { Quality } \\
\text { Standard }\end{array}$ & Mildly Polluted & Highly Polluted & Highly Polluted \\
\hline August 2016 & Mildly Polluted & $\begin{array}{l}\text { Medium } \\
\text { Polluted }\end{array}$ & Highly Polluted & Highly Polluted \\
\hline October 2016 & Highly Polluted & Mildly Polluted & Highly Polluted & Highly Polluted \\
\hline \multicolumn{5}{|l|}{ Review of RTRW: } \\
\hline Protected Area (Ha) & $1,312.05$ & 206.80 & $15,557.34$ & $8,044.47$ \\
\hline Cultivation Area (Ha) & $2,708.30$ & 170.27 & $29,580.68$ & $18,177.96$ \\
\hline Watershed Development & $\begin{array}{l}\text { Cipunagara } \\
\text { Reservoir }\end{array}$ & - & $\begin{array}{l}\text { Kandung, } \\
\text { Sadawarna and } \\
\text { Cilame } \\
\text { Reservoir, } \\
\text { Development of } \\
\text { Final Waste } \\
\text { Disposal }\end{array}$ & $\begin{array}{l}\text { Kandung } \\
\text { Reservoir, } \\
\text { Development of } \\
\text { Final Waste } \\
\text { Disposal }\end{array}$ \\
\hline
\end{tabular}

Table 4. Criteria for Segment Selection Assessment

\begin{tabular}{|c|c|c|c|}
\hline $\begin{array}{l}\text { Segment } \\
\text { Selection Scoring }\end{array}$ & Score & Assessment & Selection Indicator \\
\hline \multirow{4}{*}{$\begin{array}{l}\text { Review of } \\
\text { Existing } \\
\text { Distribution }\end{array}$} & 4 & Highest Value First & \multirow{4}{*}{$\begin{array}{l}\text { When the population, livestock and the size of } \\
\text { the agricultural sector are of high value, the } \\
\text { calculated pollutant load is high }\end{array}$} \\
\hline & 3 & Highest Value Second & \\
\hline & 2 & Highest Value Third & \\
\hline & 1 & Smallest Value & \\
\hline \multirow{4}{*}{$\begin{array}{l}\text { Review of Water } \\
\text { Quality Status }\end{array}$} & 4 & Highly Polluted & \multirow{4}{*}{$\begin{array}{l}\text { When water quality status progressively has } \\
\text { polluted status, the calculated pollutant load is } \\
\text { high }\end{array}$} \\
\hline & 3 & Medium Polluted & \\
\hline & 2 & Mildly Polluted & \\
\hline & 1 & Meet the Quality Standard & \\
\hline \multirow{4}{*}{$\begin{array}{l}\text { Review of RTRW } \\
\text { Protected and } \\
\text { Cultivation Area }\end{array}$} & 4 & Highest Value First & \multirow{4}{*}{$\begin{array}{l}\text { When the size of the protected area dominates, } \\
\text { the pollutant burden will be small, but it affects } \\
\text { the surrounding cultivation area, when the area } \\
\text { of cultivation dominates, the pollutant load is } \\
\text { high }\end{array}$} \\
\hline & 3 & Highest Value Second & \\
\hline & 2 & Highest Value Third & \\
\hline & 1 & Smallest Value & \\
\hline \multirow{4}{*}{$\begin{array}{l}\text { Review of RTRW } \\
\text { Watershed } \\
\text { Development }\end{array}$} & 4 & Most of the first Development & \multirow{4}{*}{$\begin{array}{l}\text { The more the development, the important the } \\
\text { location is in the calculation of the pollutant } \\
\text { load }\end{array}$} \\
\hline & 3 & Most of the second Development & \\
\hline & 2 & Most of the third Development & \\
\hline & 1 & No Development & \\
\hline
\end{tabular}


Table 5. Results of Segment Selection

\begin{tabular}{lllll}
\hline \multirow{2}{*}{ Review } & \multicolumn{5}{l}{ Score of Segment Cipunagara Watershed } \\
\cline { 2 - 6 } & 1 & 2 & 3 & 4 \\
\hline Review of Existing Distribution: & & & & \\
Segment Area (Ha) & 2 & 1 & 4 & 3 \\
Total Population (Person) & 2 & 1 & 3 & 4 \\
\hline Total Industry/SME & 2 & 1 & 4 & 3 \\
Area of Agricultural Land (Ha) & 2 & 1 & 3 & 4 \\
\hline Total of Livestock (number of animals) & 2 & 1 & 4 & 3 \\
\hline Review of Water Quality Status : & & & & \\
$\quad$ June 2016 & 1 & 2 & 4 & 4 \\
$\quad$ August 2016 & 2 & 3 & 4 & 4 \\
$\quad$ October 2016 & 4 & 2 & 4 & 4 \\
\hline Review of RTRW : & 2 & & & \\
Protected Area (Ha) & 2 & 1 & 4 & 3 \\
Cultivation Area (Ha) & 2 & 1 & 4 & 3 \\
Watershed Development & 23 & 15 & 42 & 38 \\
\hline Total Score & & & & 3 \\
\hline
\end{tabular}

\subsection{Existing Pollutant Load Calculation}

\subsubsection{Maximum Pollutant Load Calculation}

The selected segment is 3, which is severely polluted. In this segment, the government plans to build the Sadawarna Reservoir that is designated as raw water and irrigation. Therefore, the calculation of the maximum pollutant load using the standard water quality of river Class 1 . The results of the calculation of the maximum pollutant load are presented in Table 6.

Calculation example (BOD, flow June 2016) :

$$
\begin{aligned}
B P M= & Q \times C_{B M} \\
= & \left(48.10 \mathrm{~m}^{3} / \mathrm{s} \times 2 \mathrm{mg} / \mathrm{L} \times((1 \mathrm{~kg}) /\right. \\
& (1,000,000 \mathrm{mg}) \times\left(1 \mathrm{~m}^{3}\right) /(1,000 \mathrm{lt}) \times \\
& (1 \text { day }) /(86,400 \mathrm{~s})) \\
= & 8,311.68 \mathrm{~kg} / \text { day }
\end{aligned}
$$

\subsubsection{Actual Pollutant Load Calculation}

The calculation of actual pollutant load obtained in segment 3 of Cipunagara Watershed is based on measured flow and concentration sourced from 4 sectors, including domestic, livestock, agriculture, and industry. Table 7 shows the result of the calculation of actual pollutant load.

Calculation example: (BOD, flow June 2016)

$$
\begin{aligned}
B P M= & Q \times C_{M} \\
= & \left(48.10 \mathrm{~m}^{3} / \mathrm{s} \times 9 \mathrm{mg} / \mathrm{L} \mathrm{x}((1\right. \\
& \mathrm{kg}) /(1,000,000 \mathrm{mg}) \times\left(1 \mathrm{~m}^{3}\right) /(1,000 \mathrm{lt}) \\
& \mathrm{x}(1 \text { day }) /(86,400 \mathrm{~s})) \\
= & 37,402.56 \mathrm{~kg} / \text { day }
\end{aligned}
$$

\subsection{Existing Pollutant Load Calculation}

Based on Local Regulation Subang Regency No. 3 of 2014 and Indramayu Regency Regulation No. 1 of 2012 on Spatial Planning Area Culture, livestock became a development sector. Figure 2 shows the areas developing livestock based on RTRW document.

\subsubsection{Existing Pollutant Load Calculation}

The calculation of the maximum pollutant load is equal to that of the maximum contaminant load, which distinguishes only the river discharge 
conditions (Komarudin, 2015). The flow used is the projection for the next 5 years, which is determined using the data for similar river in West Java. According to Iskandar (2014), Ciliwung River discharge decreases $1-1.5 \%$ per year (Triane, 2015). The percentage of annual discharge can be used to discharge the Cipunagara River in calculating the maximum pollutant load (Projection). It is assumed that the Cipunagara River discharge decreases by $1 \%$ annually. The result of the calculation of the maximum pollutant load is presented in Table 8 .

Calculation example (BOD, flow June 2021)

$$
\begin{aligned}
B P M= & Q \times C_{B M} \\
= & \left(45.70 \mathrm{~m}^{3} / \mathrm{s} \times 2 \mathrm{mg} / \mathrm{L} \times((1\right. \\
& \mathrm{kg}) /(1,000,000 \mathrm{mg}) \times\left(1 \mathrm{~m}^{3}\right) /(1,000 \\
& \mathrm{lt}) \times(1 \text { day }) /(86,400 \mathrm{~s})) \\
= & 7,896 \mathrm{~kg} / \text { day }
\end{aligned}
$$

\subsubsection{Potential Pollutant Load Calculation (Projection)}

The approach taken in the development of the livestock sector involves projecting livestock in each Sub-district, where there is an increase in the number each year (Klosterman, 1990). The results using arithmetic method show that over the next 5 years, there can be an increase in the value of pollutant load in segment 3 of Cipunagara Watershed. The calculation result of potential pollution load of livestock sector is presented in Table 9.

The pollutant load calculation on the livestock sector have the potential to increase for the next 5 years. This is based on the development of the documents in the RTRW Subang and Indramayu Regency (Kusumaningtyas and Chofyan, 2013). Additionally, Cipunagara Sub-district can develop in terms of productivity, breeding and cutting chicken in the next 5 years. The chicken sector has the potential to contribute more pollutant expenses than in previous years. Also, ruminant animals such as cows, buffalo, sheep

\begin{tabular}{|c|c|c|c|c|c|c|c|c|}
\hline \multirow{2}{*}{ No } & \multirow{2}{*}{ Parameter } & \multirow{2}{*}{$\begin{array}{l}\text { Water Quality } \\
\text { Standard } \\
\text { Class I } \\
(\mathrm{mg} / \mathrm{L})\end{array}$} & \multicolumn{3}{|c|}{ Measurement Flow (m³/s) } & \multicolumn{3}{|c|}{ Maximum Pollutant Load (kg/day) } \\
\hline & & & June & August & October & June & August & October \\
\hline 1 & TSS & 50.00 & & & & $207,792.00$ & $58,881.60$ & $738,720.00$ \\
\hline 2 & BOD & 2.00 & & & & $8,311.68$ & $2,355.26$ & $29,548.80$ \\
\hline 3 & COD & 10.00 & 48.10 & 13.63 & 171.00 & $41,558.40$ & $11,776.32$ & 147.74 \\
\hline 4 & Total-P & 0.20 & & & & 831.17 & 235.52 & $2,954.88$ \\
\hline 5 & Total-N & 10.00 & & & & - & - & - \\
\hline
\end{tabular}
and goats constitute the developments in Cisalak, Jalan Cagak, Kasomalang, Tanjungsiang, Cijambe, Cibogo and Gantar Sub-district.

Table 6. Maximum Pollutant Load Segment 3 Cipunagara Watershed

Table 7. Actual Pollutant Load Segment 3 Cipunagara Watershed

\begin{tabular}{llllllll}
\hline \multirow{2}{*}{ No } & \multirow{2}{*}{ Parameter } & \multicolumn{2}{l}{ Measurement Concentration $(\mathrm{mg} / \mathrm{L})$} & \multicolumn{3}{l}{ Actual Pollutant Load $(\mathrm{kg} / \mathrm{day})$} \\
\cline { 3 - 8 } & & June & August & October & June & August & October \\
\hline 1 & TSS & 28 & 52 & 15 & $116,363.52$ & $61,236.86$ & $221,616.00$ \\
2 & BOD & 9.00 & 24.50 & 7.05 & $37,402.56$ & $28,851.98$ & $104,159.52$ \\
3 & COD & 27.6 & 75.8 & 25.4 & $114,701.18$ & $89,264.51$ & $375,269.76$ \\
4 & Total-P & 0.0043 & 0.0260 & 0.0800 & 17.87 & 30.62 & $1,181.95$ \\
5 & Total-N & - & - & - & - &. & - \\
\hline
\end{tabular}


Table 8. Maximum Pollutant Load Segment 3 Cipunagara Watershed in 2021

\begin{tabular}{|c|c|c|c|c|c|c|c|c|}
\hline \multirow{2}{*}{ No } & \multirow{2}{*}{ Parameter } & \multirow{2}{*}{$\begin{array}{l}\text { Water Quality } \\
\text { Standard Class } \\
\text { I (mg/L) }\end{array}$} & \multicolumn{3}{|c|}{ Projection of River Flow $\left(\mathrm{m}^{3} / \mathrm{s}\right)$} & \multicolumn{3}{|c|}{ Maximum Pollutant Load (kg/day) } \\
\hline & & & June & August & October & June & August & October \\
\hline 1 & TSS & 50.00 & & & & 197,402 & 55,938 & 701,784 \\
\hline 2 & BOD & 2.00 & & & & 7,896 & 2,238 & 28,071 \\
\hline 3 & COD & 10.00 & 45.70 & 12.90 & 162.50 & 39,480 & 11,188 & 140,357 \\
\hline 4 & Total-P & 0.20 & & & & 790 & 224 & 2,807 \\
\hline 5 & Total-N & 10.00 & & & & - & - & - \\
\hline
\end{tabular}

Table 9. Results of Calculation Potential Pollutant Load Livestock Sector Year 2021

\begin{tabular}{lllllll}
\hline \multirow{2}{*}{ Parameter } & \multicolumn{5}{c}{ Pollutant Load (kg/day) } \\
\cline { 2 - 7 } & 2016 & 2017 & 2018 & 2019 & 2020 & 2021 \\
\hline BOD & $1,668.76$ & $1,733.40$ & $1,797.60$ & $1,861.79$ & $2,017.14$ & $2,081.25$ \\
COD & $4,053.74$ & $4,212.67$ & $4,370.44$ & $4,528.21$ & $4,905.73$ & $5,063.29$ \\
N-TOT & 8.72 & 9.22 & 9.71 & 10.21 & 12.85 & 13.34 \\
P-TOT & 1.75 & 1.81 & 1.87 & 1.93 & 2.10 & 2.17 \\
\hline
\end{tabular}

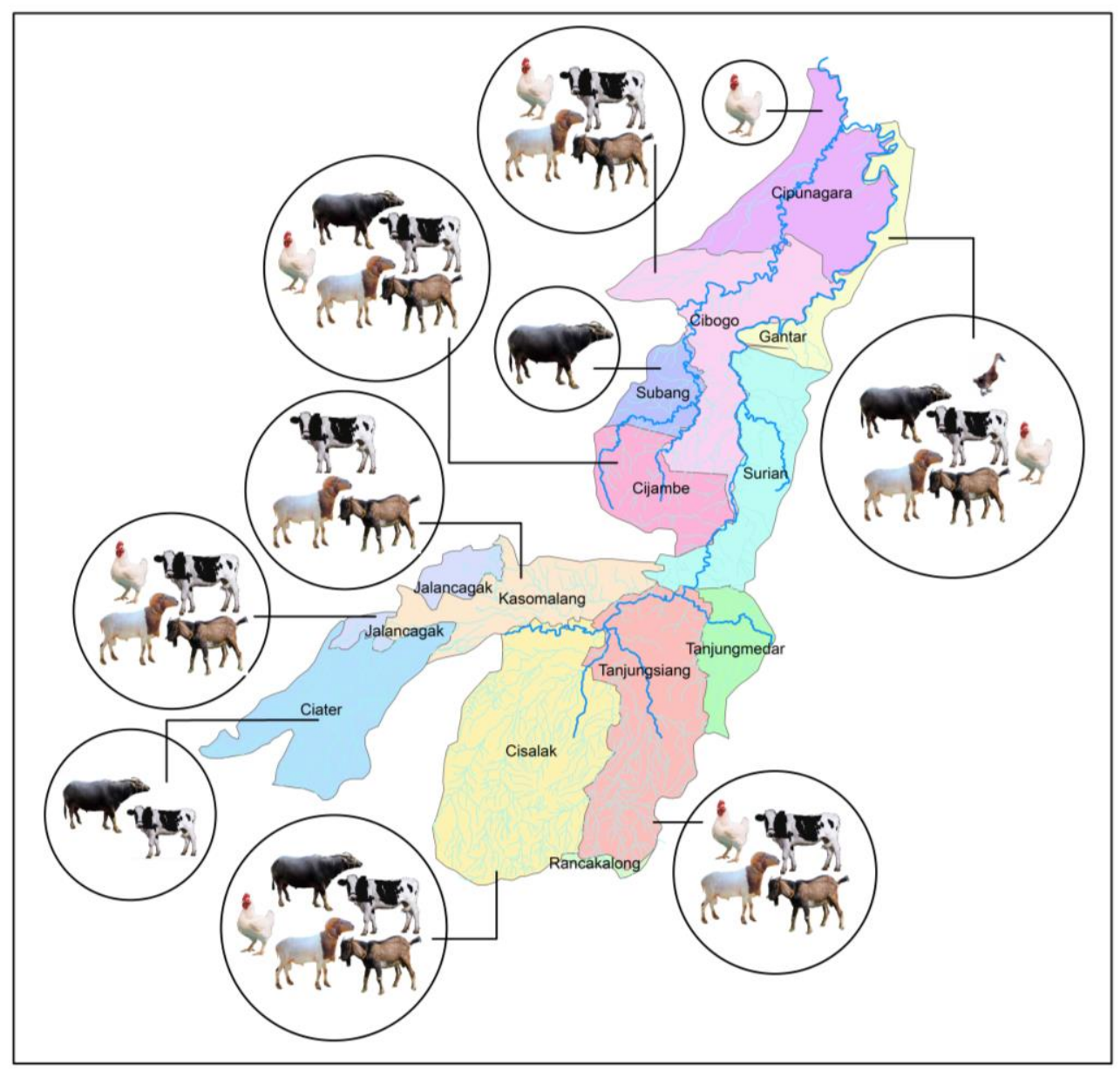

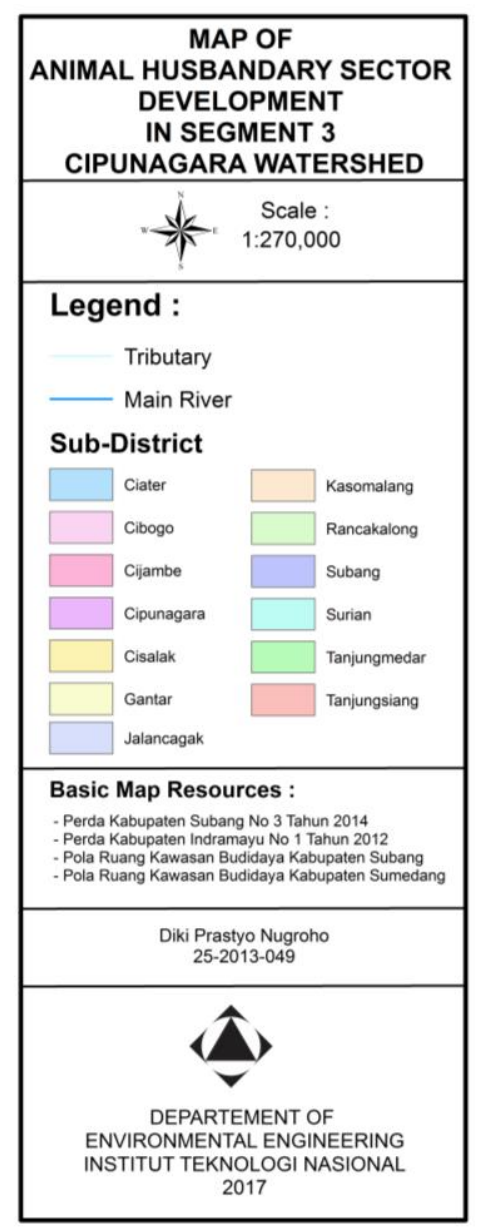

Figure 2. Map of Livestock Sector Development in Segment 3 Cipunagara Watershed 


\subsection{Comparison of Pollutant Load Existing and Projection}

Comparison of pollutant load involve examining the conditions in the potential year (2016) and possible capability in the next 5 years (2021). However, the existing pollutant load was obtained from water sampling, which represented pollution from four main sectors, including domestic, livestock, agriculture and industry. Therefore, in the comparison, actual pollution load should be divided proportionally into the four main sectors, which is shown in Table 10.

In order to compare the existing contaminant load and the potential of the livestock sector, it is necessary to divide the proportion of the maximum and actual pollutant load generated from each parameter. The following is the proportion of the maximum and actual pollutant load of the livestock sector:

Calculation example (BOD)

$\Sigma$ Livestock Sector of $\quad=1,668.76 \mathrm{~kg} / \mathrm{day}$

Pollutant Load

$\Sigma$ Total Existing of Pollutant $=6,356.58 \mathrm{~kg} / \mathrm{day}$

Load

\%Livestock Sector of

$=(1,668.76 / 6,356.58) \times 100 \%$

Pollutant Load

$$
=26.25 \%
$$

$\Sigma$ Maximum of Pollutant $=8,311.68 \mathrm{~kg} /$ day

Load (Flow July 2016)

$$
\begin{array}{lll}
\begin{array}{l}
\text { \% Livestock of BOD } \\
\text { Pollutant Load }
\end{array} & 26.25 \% \\
\begin{array}{l}
\text { \% Proportion of BOD } \\
\text { Maximum Pollutant Load }
\end{array} & =8,311.68 \times 26.25 \% \\
& =\quad 2,182.03 \mathrm{~kg} / \mathrm{day}
\end{array}
$$

\subsubsection{Comparison of Existing Pollutant Load}

Livestock sector of pollutant load when the existing condition (2016) involves comparison between the maximum and the actual load is presented in Table 11.

Existing pollutant load conditions resulting from the livestock sector exceeded the maximum pollutant load of BOD and COD parameters in each season. Only $\mathrm{P}$-Total parameters still receive pollutant load from the livestock sector. This is because the value obtained has not exceeded the maximum pollutant load.

\subsubsection{Comparison of Projection Pollutant Load}

Livestock sector of pollutant load in the projection condition (2021) involves the comparison between the maximum and potential pollution load. The result is presented in Table 12 .

\begin{tabular}{|c|c|c|c|c|c|}
\hline \multirow{2}{*}{ Parameter } & \multicolumn{4}{|c|}{ Pollutant Load (kg/day) } & \multirow{2}{*}{ Total } \\
\hline & Domestic & Livestock & Agriculture & Industry & \\
\hline \multirow{2}{*}{ BOD } & $2,485.07$ & $1,668.76$ & 107.24 & $2,095.50$ & \multirow{2}{*}{$6,356.58$} \\
\hline & $(40.6 \%)$ & $(23.02 \%)$ & $(1.08 \%)$ & $(34.58 \%)$ & \\
\hline \multirow{2}{*}{ COD } & $3,416.98$ & $4,053.74$ & \multirow{2}{*}{-} & \multirow{2}{*}{-} & \multirow{2}{*}{$7,470.72$} \\
\hline & $(50.03 \%)$ & (49.97\%) & & & \\
\hline \multirow{2}{*}{ TSS } & $2,360.82$ & & 2.03 & \multirow{2}{*}{-} & \multirow{2}{*}{$2,362.86$} \\
\hline & $(99.91 \%)$ & - & $(0.09 \%)$ & & \\
\hline \multirow{2}{*}{ N-Total } & 121.15 & 8.72 & 112.47 & \multirow{2}{*}{-} & \multirow{2}{*}{242.33} \\
\hline & $(49.66 \%)$ & $(3.04 \%)$ & $(47.30 \%)$ & & \\
\hline \multirow{2}{*}{ P-Total } & 13.05 & 1.75 & 56.23 & \multirow[b]{2}{*}{-} & \multirow{2}{*}{71.03} \\
\hline & $(18.04 \%)$ & $(2.16 \%)$ & (79.80\%) & & \\
\hline
\end{tabular}

The comparison between the maximum and the potential pollutant load of the projection result shows the projected condition of the polluted load value of the livestock sector.

Table 10. Recapitulation of Potential Pollutant Load 
Table 11. Comparison Maximum and Actual Pollutant Load Livestock Sector

\begin{tabular}{lllllll}
\hline \multirow{2}{*}{ Parameter } & \multicolumn{2}{l}{ Maximum Pollutant Load (kg/day) } & \multicolumn{3}{l}{ Actual Pollutant Load (kg/day) } \\
\cline { 2 - 7 } & June & August & October & June & August & October \\
\hline BOD & $2,182.03$ & 618.32 & $7,757.31$ & $9,819.12$ & $7,574.37$ & $27,344.50$ \\
COD & $22,550.30$ & $6,390.03$ & $80,168.43$ & $62,238.83$ & $48,436.45$ & $203,627.81$ \\
TSS & - & - & - & - & - & - \\
N-Tot & - & - & - & - & - & - \\
P-Tot & 20.46 & 5.80 & 72.72 & 0.44 & 0.75 & 29.09 \\
\hline
\end{tabular}

Table 12. Comparison Maximum and Potential Pollutant Load Projection Result (2021)

\begin{tabular}{|c|c|c|c|c|}
\hline \multirow{2}{*}{ Parameter } & \multicolumn{3}{|c|}{ Maximum Pollutant Load (kg/day) } & \multirow{2}{*}{ Potential Pollutant Load (kg/day) } \\
\hline & June & August & October & \\
\hline BOD & $1,817.68$ & 515.07 & $6,462.03$ & $2,081.25$ \\
\hline COD & $19,728.40$ & $5,590.40$ & $70,136.29$ & $5,063.29$ \\
\hline TSS & - & - & - & - \\
\hline N-Tot & - & - & - & 13.34 \\
\hline P-Tot & 17.06 & 4.83 & 60.63 & 2.17 \\
\hline
\end{tabular}

\section{CONCLUSIONS}

The pollutions load from the livestock sector generated in the Segment 3 of Cipunagara watershed increase as the number of cattle, buffalo, horses, goats, sheep, chickens and ducks grow. This is shown by the values of existing and projected pollutant loads, for different parameters, including BOD, COD, N-Total, and PTotal. The existing and projected pollution loads show an increase every year, indicating the influence of the development of the livestock sector. Also, there are significant increase when the river flow decreases. Compared to the overall loads from other sectors, it is shown that the load from the livestock sector exceeded its maximum. The local governments and other stakeholders need to seek relevant strategies for reducing the load from livestock activities to ensure the Cipunagara River, particularly Segment 3, can be used as the source of raw water.

\section{DISCLAIMER}

The authors declare no conflict of interest.

\section{ACKNOWLEDGMENTS}

This research was supported by the Institution of Research and Community Services of Institut Teknologi Nasional (ITENAS) Bandung.

\section{REFERENCES}

Asdak, C., 2002. Hidrologi dan pengelolaan Daerah Aliran Sungai: Yogyakarta: Gadjah Mada University Press.

Effendi, H., 2003. Telaah Kualitas Air, bagi Pengelolaan Sumber Daya dan Lingkungan Perairan. Yogyakarta: Penerbit Kanisius.

Hallock, D., 1988. Water Quality Index. Memo to J. Bernhardt.

Hidrijanti, A. A., Juwana, I., and Sari, Y. S., 2019. Kajian Daya Tampung Beban Pencemaran Sungai Cibeureum DAS Citarum Sektor Pertanian. Jurnal Teknologi Lingkungan Lahan Basah, 7(2), pp. 7280.

Hikmat, R., and Juwana, I.,2019). Pollution load of Cisangkan River: The domestic sector. IOP 
Conference Series: Earth and Environmental Science.

Iskandar, 2007. Panduan Pelatihan Pengelolaan Kualitas Air. Jakarta: Puslitbang Sumber Daya Air Kementrian Pekerjaan Umum.

Isserman, A. M. ,1977. The Accuracy of Population Projections for Subcounty Areas. Journal of the American Institute of Planners, 43(3), pp. 247-259.

Juwana, I., Muttil, N., and Perera, B., 2014. Application of West Java Water Sustainability Index to Citarum Catchment in West Java, Indonesia. Water Science and Technology: Water Supply, 14(6), pp. 1150-1159.

Klosterman, R. E., 1990. Community analysis and planning techniques: Rowman \& Littlefield Publishers.

Komarudin, M., 2015. Analisis Daya Tampung Beban Pencemar Sungai Pesanggrahan (Segmen Kota Depok) dengan Menggunakan Model Numerik dan Spasial. Jurnal Pengelolaan Sumberdaya Alam dan Lingkungan, Vol.5 No.2

Kusumaningtyas, R., and Chofyan, I., 2013. Pengelolaan Hutan dalam Mengatasi Alih Fungsi Lahan Hutan di Wilayah Kabupaten Subang. Jurnal Perencanaan Wilayah dan Kota, 13(2), pp.111.

Sari, I., Sri, Y., Sunjaya, D. K., Shimizu-Furusawa, H., Watanabe, C., and Raksanagara, A. S., 2018. Water Sources Quality in Urban Slum Settlement along the Contaminated River Basin in Indonesia:
Application of Quantitative Microbial Risk Assessment. Journal of environmental and Public Health 2018, pp. 1-7.

Triane, D., 2015. Pemodelan Kualitas Air Menggunakan Qual2Kw (Studi Kasus: Sungai Ciliwung), Bandung: Thesis Report. Institut Teknologi Bandung, Bandung.

Trofisa, D., 2011. Kajian Beban Pencemaran dan Daya Tampung Pencemaran Sungai Ciliwung di Segmen Kota Bogor, Bogor: Thesis Report. Departement of Forest Resource Conservation and Eco-tourism, Faculty of Forestry Institut Pertanian Bogor.

Wu, Y.Y., Li, Y.S., and Liu, W.J., 2006. Study on Gini Coefficient Method of Total Pollutant Load Allocation for Water Bodies [J]. Research of environmental sciences, 2, 018.

Yang, M., Lu, M., Sheng, L., and Wu, H., 2018. Study of The Spatial and Temporal Distribution of Accumulated Solids in an Experimental VerticalFlow Constructed Wetland System. Science of The Total Environment, Vol 628-629, pp. 509-516.

Yogaswara, M. F., Juwana, I., Sari, Y. S., and Bakari, H., 2019. A Study of Pollution Load Capacity of the Industrial Sector in CIbabat River in the Watershed of Citarum River. Indonesian Journal of Urban and Environmental Technology, 3(1), pp. 67-83.

Yusuf, I. A., 2014. Emisi Hewan Ternak Acuan Untuk Menghitung Potensi Beban Pencemaran Limbah Hewan. Jurnal Sumber Daya Air, 10(1), pp. 85-96. 